\title{
Stepped spillway with pre-aeration by a deflector: flow characteristics
}

\section{Vertedouros em degraus com pré-aeração por um defletor: características do escoamento}

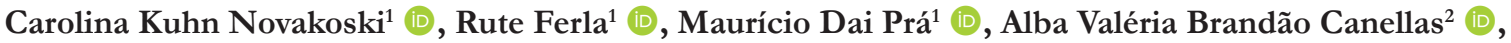 \\ Marcelo Giulian Marques ${ }^{1}$ (D) \& Eder Daniel Teixeira ${ }^{1}$ (D) \\ ${ }^{1}$ Instituto de Pesquisas Hidráulicas, Universidade Federal do Rio Grande do Sul, Porto Alegre, RS, Brasil \\ ${ }^{2}$ Furnas Centrais Elétricas S.A., Rio de Janeiro, RJ, Brasil \\ E-mails: carolina.novakoski@ufrgs.br (CKN),rute.ferla@ufrgs.br (RF), mauricio.daipra@ufrgs.br (MDP), alba@furnas.com.br (AVBC), \\ mmarques@iph.ufrgs.br(MGM), eder.teixeira@ufrgs.br (EDT)
}

\begin{abstract}
Stepped spillways aim to dissipate part of the upstream energy during the flow passage by the chute. However, the use of these structures is limited to a restrict range of specific discharges due to the risk of cavitation damage. As the air entrainment into the flow assists the concrete protection against the aforementioned damages, a possible solution by aerators installed along the chute, already disseminated to smooth chutes, is being studied to be used also in stepped spillways. The purpose of the present paper is to characterize a flow over a stepped chute with induced aeration by deflector and air supply by an airtight chamber trough tests conducted on a reduced scale physical model. The main regions observed during the tests are presented and were developed four equations that allow to approximately predict the location of the main regions for a given spillway.
\end{abstract}

Keywords: Stepped spillway; Aerated flows; Reduced hydraulic models; Deflector influence.

\section{RESUMO}

Vertedouros em degraus têm por objetivo dissipar, ao longo da calha, uma parcela da energia do escoamento. No entanto, a utilização dessas estruturas está limitada a uma restrita faixa de vazões específicas devido aos riscos de cavitação e erosão. Como a introdução de ar no escoamento permite a proteção do concreto contra os danos mencionados, uma possível solução por aeradores instalados ao longo da calha, já difundida para calhas lisas, está sendo estudada para ser utilizada também em vertedouros em degraus. A presente pesquisa tem o propósito de caracterizar um escoamento sobre vertedouros em degraus com aeração induzida por defletor e fornecimento de ar por uma câmara de ar através de ensaios realizados em um modelo físico reduzido. São apresentadas zonas e posições características do escoamento observadas durante os ensaios e também, quatro equações que permitem calcular, aproximadamente, a sua localização em um protótipo.

Palavras-chave: Vertedouro em degraus; Escoamento aerado; Modelos hidráulicos reduzidos; Influência do defletor. 


\section{INTRODUCTION}

Stepped spillway structures are an alternative to dissipate a significant amount of flow energy along a chute. This solution allows a reduction of the downstream dissipation structure, resulting in lower total construction cost. In order to ensure energy dissipation and reduce cavitation risks, it is necessary that occurs air entrainment into the flow. When the boundary layer reaches the flow free surface turbulence induces strong aeration through shear stresses that overcome the combined buoyancy and surface tension (Gonzalez \& Chanson; 2007; Zhang \& Chanson, 2016). Increasing the discharge, the inception point occurs far downstream in relation with lower discharges. Depending on the specific discharge, the boundary layer may not reach the free surface of the flow, then the inception point may not occur or occurs far downstream, exposing the chute structure to risks of cavitation damages.

Extensive studies were developed aiming to study flow behavior and pressure heads on stepped spillways (e.g. Chanson, 1994; Sánchez-Juny et al., 2008; Zhang et al., 2012; Xu et al., 2015; Parsaire et al., 2016; Zindovic et al., 2016; Zhang \& Chanson, 2017, 2018). However, according to specific studies, implementation of stepped spillways is limited to a restricted range of specific discharge, in order to avoid cavitation damage, that may take on values from 10 to $17 \mathrm{~m}^{3}$ /s/m (Gomes (2006), Amador et al. (2009) and Novakoski et al. (2018) up to 20 to $30 \mathrm{~m}^{3} /$ (sm) (Matos et al., 2001; Boes \& Hager, 2003).

Considering the current trend of spillways with high specific discharges and the advantages of stepped spillways, are being conducted studies in order to increase these limits of the flow specific discharges through induced aeration. Aerator elements, such as deflectors and piers combined with an air supply system are tested. The corresponding air entrainment reduces the cavitation risks and, according to Peterka (1953), air concentrations starting at $2 \%$ in relation to water flow, allow some concrete protection and, from 6 to $8 \%$, are enough to protect concrete structures. This solution is already disseminated to be utilized in smooth chutes. Some papers that focus on the effect of aerators elements on flow over smooth chutes are: Pfister \& Schwindt (2014), Teng et al. (2016), Yang et al. (2018).

Further investigations regarding flow behavior and air concentration in flows on stepped spillways with induced aeration were performed by Pfister et al. (2006), Mojtaba et al. (2015) and Terrier (2016). The jet generated by a deflector allows for an increasing amount of air into the flow, dissipating energy and reducing its hydrodynamic impact (Pfister \& Hager, 2009). This paper aims to characterize flow behaviors when submitted to induced aeration by different deflector heights. Typical zones of the induced aeration flow will be presented based on visual observations and four equations are proposed to make it possible to identify the zones limits in a determined prototype.

\section{Experimental setup}

The measurements were conducted in a 1:10 reduced scale physical model of a stepped spillway built at Laboratório de Hidráulica Experimental (LAHE) owned by Furnas Centrais Elétricas S. A. (Brazil). The model, built in concrete, consists of a $1.15 \mathrm{~m}$ wide chute with 20 steps and a Creager type ogee crest. The step height (hd) of the model is $9 \mathrm{~cm}$ (the stepped spillway model doesn't have transition steps) and the chute angle is $53^{\circ}$. Four deflectors with $0.015,0.018,0.027$ and $0.036 \mathrm{~m}$ height $(\mathrm{t})$, corresponding, respectively, to angles $(\theta)$ of $8,9,14$ and $18^{\circ}$ in relation with the pseudo bottom, were tested. The deflectors were named as t15, t18, t27 and t36 as shown in Figure 1, and are placed exactly where the constant slope begins, between the ogee and the horizontal face of the first step.
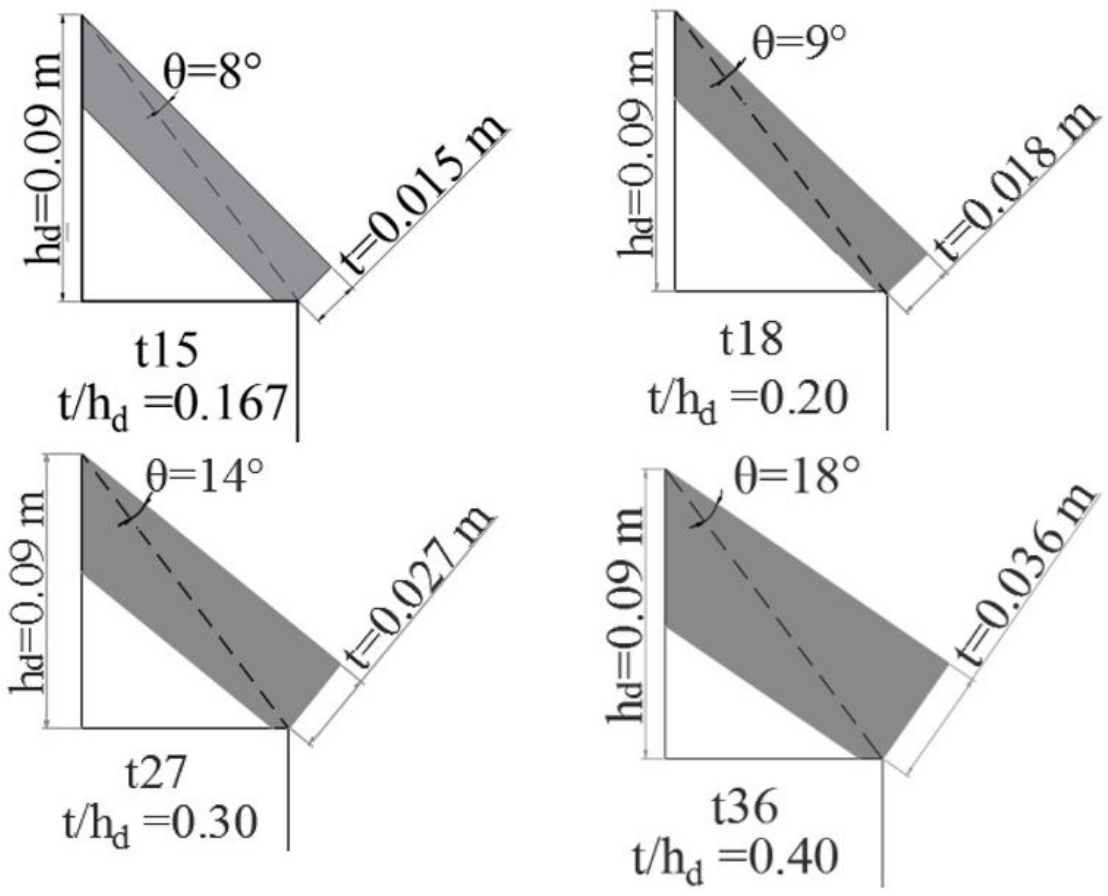

Figure 1. Geometry of the deflectors tested. 
The air is supplied through an airtight chamber connected to a transversal slot, opened over the whole length of the chute and with $0.045 \mathrm{~m}$ of height in the vertical face of the first step, below the deflector. On the opposite side of the chamber, a circular orifice of $0.1 \mathrm{~m}$ diameter provides the air entrainment. Figure 2 and Figure 3 show, respectively, a scheme and a photograph of the air entrainment in the model.

The tests were conducted with discharges between 115 and 409 l/s, corresponding to Froude numbers $\left(F_{\mathrm{r}}=\mathrm{V} /\left((\mathrm{gh})^{1 / 2}\right)\right)$ ranging from 6.10 to 3.77 , Webber numbers $\left(\mathrm{We}=\mathrm{V} /\left((\sigma / \mathrm{Qh})^{1 / 2}\right)\right)$ from 67 to 133 and Reynolds numbers from $1.00 \mathrm{E}+05$ to $3.53 \mathrm{E}+05(\mathrm{Re}=\mathrm{Vh} / \mathrm{u})($ Table 1$)$. Here, $\mathrm{V}$ is the approach flow velocity, $\mathrm{g}$ the acceleration gravity, $\mathrm{h}$ the approach flow depth, $\sigma$ the surface tension of water, $\varrho$ the water density and $\checkmark$ the kinematic water viscosity. The dimensionless numbers are defined at the deflector. A total of 28 tests with induced aeration were performed (that is, seven discharges for each deflector).

\section{RESULTS AND ANALYSIS}

Visual analysis has indicated that the flow over a stepped chute, with aeration induced by a specific deflector and air supply by the same system, follows the pattern shown in Figure 4. Five main zones were observed and described as follows.

Jet generation region: This region is characterized by the generation of a jet through the flow passage over the deflector. The jet is formed by a blackwater core with thin layers of aeration on upper and lower air-water interface. This occurs due to the air resistance to flow. The jet begins on the final part of the deflector and ends when the flow reaches the stepped chute at the jet impact point.

Black water reduction region: After the jet impact, a lower aeration layer is formed in the flow, over the steps. The aeration layer thickness increases along the chute until it reaches the aeration on the upper part of the flow. Thus, the blackwater core reduces along the stepped chute until the point where the upper and lower aerations join. Furthermore, it can be noticed a spray formation downstream from the position where the flow reaches the chute. Probably, this phenomenon occurs due to the jet impact on the steps as can be seen in Figure 5.

Fully aerated region: When the blackwater core ends, the flow becomes fully aerated, which means that there is air along the entire flow depth. This region can be subdivided in other three regions: transition, gradually varied flow and quasi-uniform flow. In the transition region, the flow is fully aerated, however a difference between the upper and lower aerations still perceptible. Furthermore, air concentration is smaller than in downstream regions. In the gradually varied flow zone, it is not possible to visualize any difference on the aeration along the flow depth. In addition, a disturbance on the flow surface and an increase on the flow depth along the chute are recognizable. The flow depth increases along the chute until it reaches the normal depth and the quasi-uniform flow region starts.

The limits of each main region observed on all conducted tests were: jet impact, blackwater reduction end, gradually varied flow beginning and quasi-uniform flow beginning. The distances from the beginning of the steps to the characteristic position above
Besides that, it was also analyzed the data Reynolds and Weber numbers dependence. It was observed that exists a relation between these dimensionless numbers and the characteristics

Table 1. Dimensionless numbers defined at the deflector.

\begin{tabular}{ccccc}
\hline $\mathbf{Q}(\mathbf{1} / \mathbf{s})$ & $\mathbf{q}\left(\mathbf{m}^{3} / \mathbf{( s . m )}\right)$ & $\mathbf{F}_{\mathbf{r}}$ & $\mathbf{R}_{\mathbf{e}}$ & $\mathbf{W}_{\mathbf{e}}$ \\
\hline Q1 $=115$ & 0.100 & 6.10 & $1.00 \mathrm{E}+05$ & 67 \\
Q2 $=144$ & 0.125 & 5.58 & $1.25 \mathrm{E}+05$ & 76 \\
Q3 $=173$ & 0.150 & 5.19 & $1.50 \mathrm{E}+05$ & 84 \\
Q4 $=230$ & 0.200 & 4.66 & $2.00 \mathrm{E}+05$ & 98 \\
Q5 $=316$ & 0.275 & 4.16 & $2.75 \mathrm{E}+05$ & 116 \\
Q6 $=380$ & 0.330 & 3.83 & $3.24 \mathrm{E}+05$ & 126 \\
Q7 $=409$ & 0.355 & 3.77 & $3.53 \mathrm{E}+05$ & 133 \\
\hline
\end{tabular}

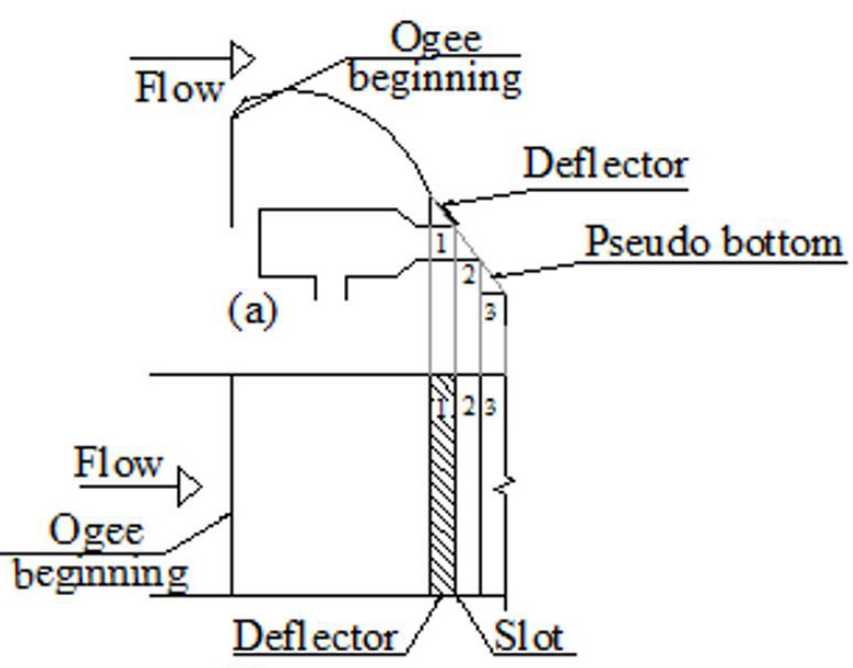

(b)

Figure 2. Air entrainment system into the model (a) lateral view and (b) plan view.

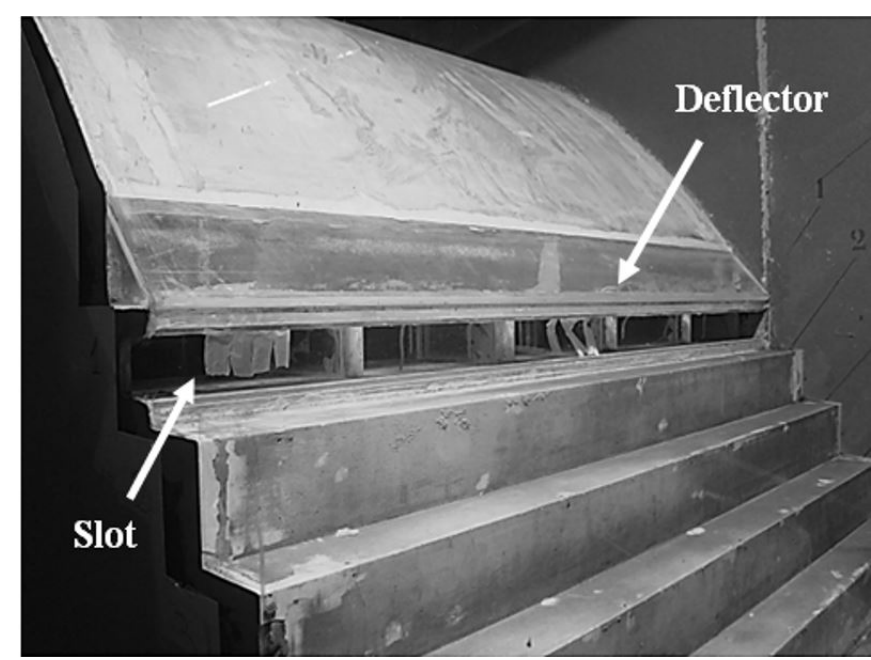

Figure 3. Deflector and transversal slot in the model. 


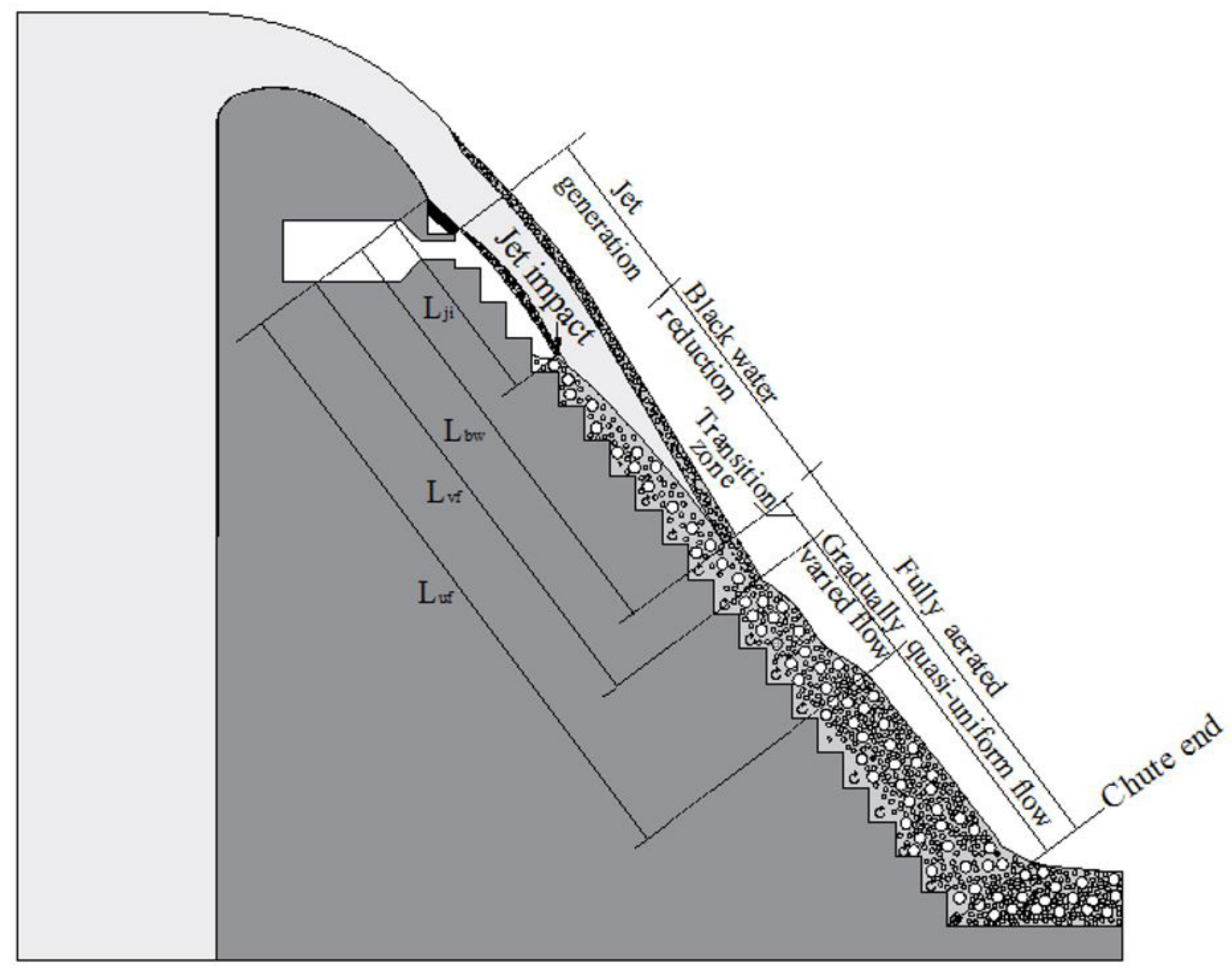

Figure 4. Flow pattern scheme.
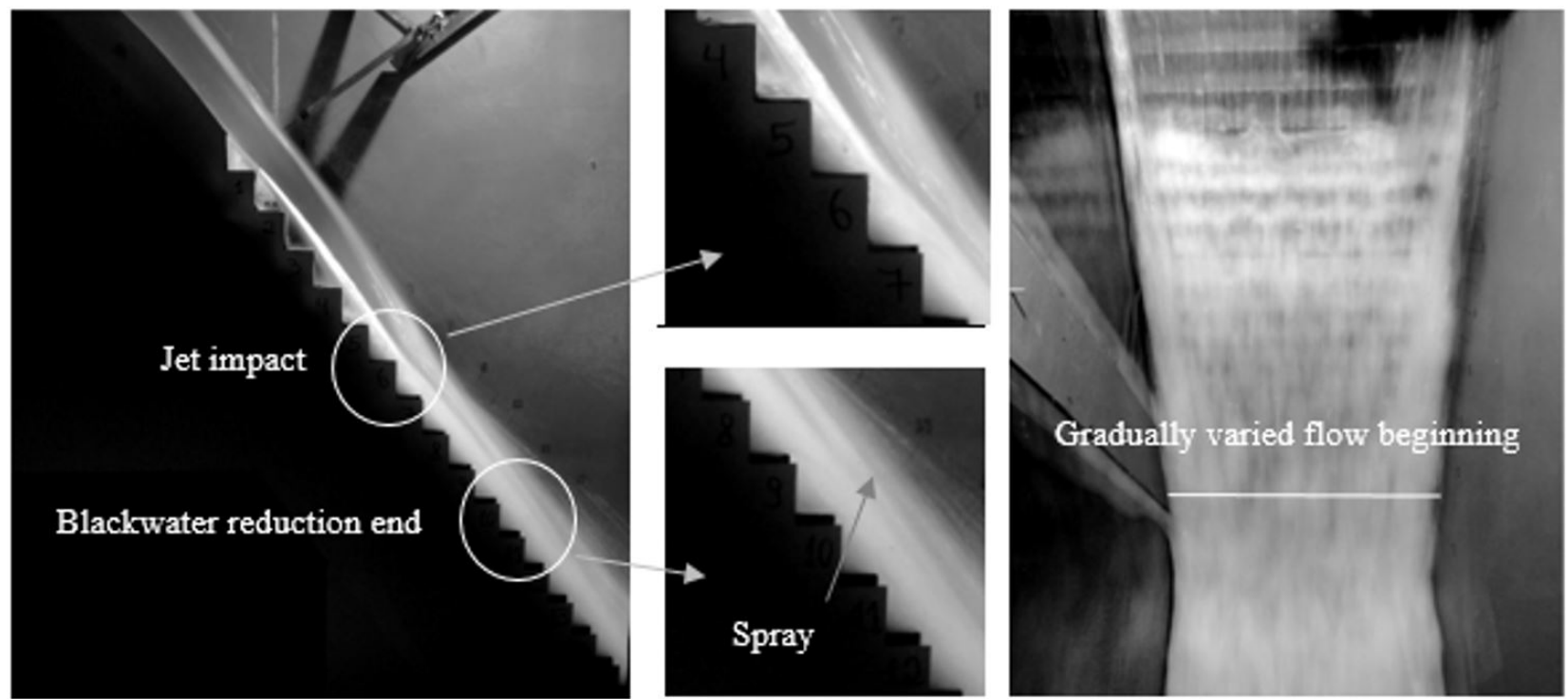

Figure 5. Limits of main regions for the test with deflector of $0.015 \mathrm{~m}$ high and with discharge Q6. 
mentioned are $\mathrm{L}_{\mathrm{i},}, \mathrm{L}_{\mathrm{bw}}, \mathrm{L}_{\mathrm{vf}}$ and $\mathrm{L}_{\mathrm{uf}}$, respectively. In Figure 4, the position where the chute is finished is indicated. Figures 5, 6 and 7 show the limits of each main region observed in the physical model.

The observed results for all tests with induced aeration are presented in Figure 8. The values of $\mathrm{q}$ are the specific discharge $\left(\mathrm{m}^{3} /(\mathrm{sm})\right)$ and distance $\mathrm{t}$ is the deflector height $(\mathrm{m})$. About these results the following observations apply:

Jet Impact: The specific discharge has little influence on the jet impact position, contrary to deflector height (Figure 8a). As expected, increasing deflector height, the jet length also increases. Distances in the jet impact position between the lowest and the highest deflector was about $0.6 \mathrm{~m}$ along the chute, which corresponds to 8 steps. This means that the jet impact occurred downstream the step 12 with deflectors $\mathrm{t} 27$ and $\mathrm{t} 36$.

Blackwater reduction end: The specific discharge has a significant influence on blackwater end position for the two lower deflectors (t15 and t18) and minor influence for the higher deflectors (t27 and t36). See Figure 8b. Using the deflectors t15 and t18, a discharge increase results in a further downstream blackwater core. Contrarily, for the deflectors $\mathrm{t} 27$ and $\mathrm{t} 36$, an increase in discharge means that the blackwater core ends upstream in relation to higher discharges. A possible interpretation of this behavior may be that for the deflectors $\mathrm{t} 15$ and $\mathrm{t} 18$, an increasing on flow rate means a deeper flow depth, which also means a deeper black water core and, consequently, a further downstream blackwater core end. For same deflectors, for lower discharges, immediately downstream of the impact position, the flow is totally aerated, and the black water end coincides with the jet impact position (see in Figure 6). However, deflectors $\mathrm{t} 27$ and $\mathrm{t} 36$ originate a longer jet and none of the tested discharge was enough to provide black water core that ends downstream of the jet impact position.

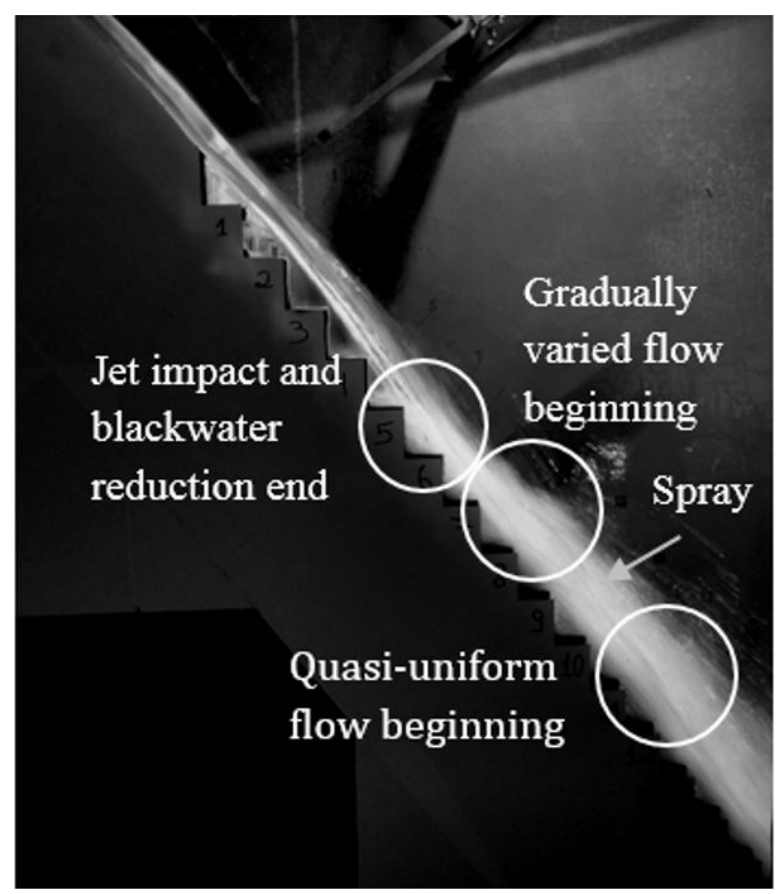

Figure 6. Limits of main regions observed for the test with deflector of $\mathrm{t} 15$ and discharge Q1.
Gradually varied flow beginning: Contrarily to the jet impact position, specific discharge has a significant influence on the beginning of gradually varied flow, as well as the deflector height (Figure 8c). For higher discharges and higher deflector heights, the gradually varied flow begins downstream in relation to the lower ones. For higher discharges (Q5, Q6 and Q7), the gradually varied flow begins in the final part of the chute for all the tested deflectors. Especially for the deflectors $\mathrm{t} 27$ and t 36 , the gradually varied flow started downstream in the step 17 for all the tested discharges. For the higher ones, it has occurred on the last step.

Quasi-uniform flow beginning: The quasi-uniform flow beginning was observed only for the deflector t 15 with all tested discharges and for deflector $\mathrm{t} 18$ with the lowest discharge. It was observed that, in this situation, the specific discharge does not have a significant influence on the region position. For the remaining deflectors, as the jet length is larger, the quasi-uniform flow condition wasn't identified until step 20.

The same results presented in Figure 8 are shown now in Figure 9, with Froude number as a function of the distance from the beginning of the steps to the limit of each zone (characteristic positions) and the deflector angle.

It can be noted that it is possible to describe all the characteristic positions as a power low relation (Equation 1) just changing the values of coefficients "a" and "b".

$F_{r}=a\left(\frac{L_{r e f}}{h_{o} \operatorname{sen} \theta}\right)^{b}$

Table 2 shows the coefficients obtained for each characteristic position. Then this curve can be adjusted to each characteristic position and can help to predict approximately the location where each region will occur in a determined prototype.

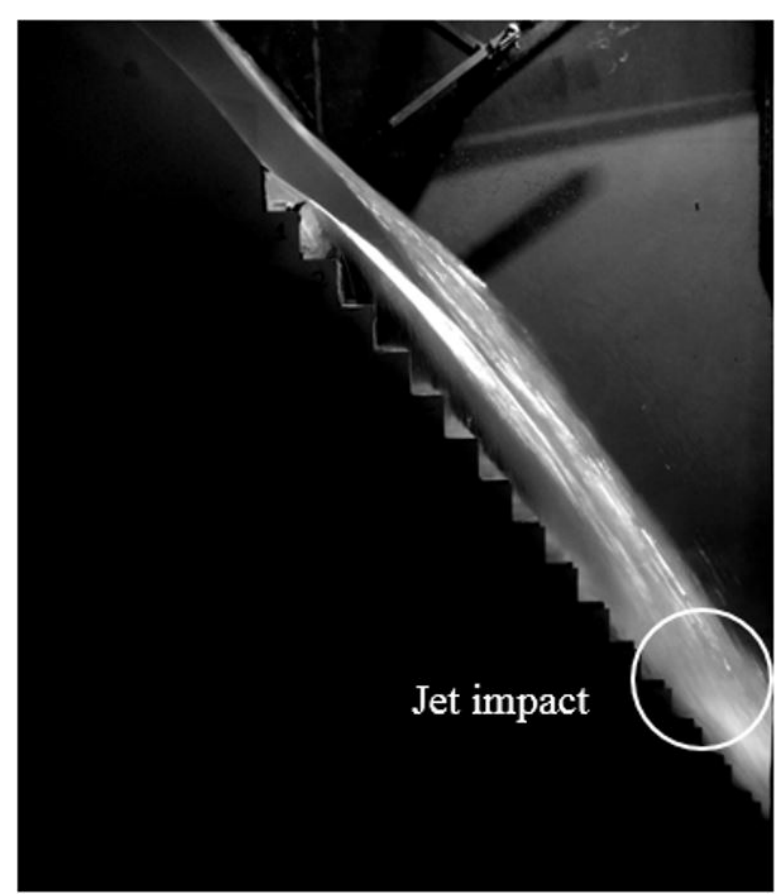

Figure 7. Limits of main regions observed for the test with deflector $\mathrm{t} 36$ and discharge Q6. 

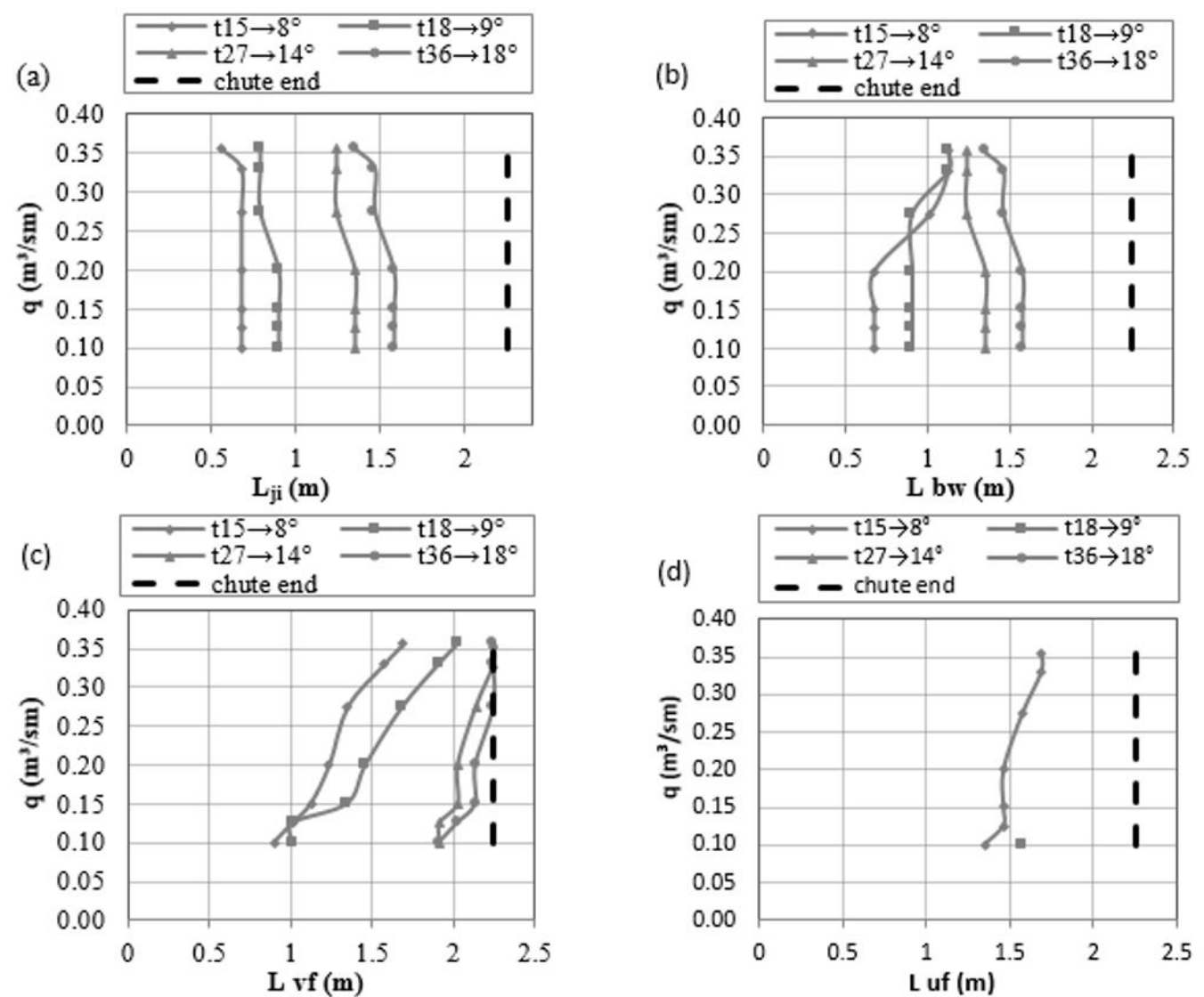

Figure 8. Limits of main regions of induced aeration flow: (a) Jet impact; (b) blackwater reduction end; (c) gradually varied flow beginning; and (d) quasi-uniform flow beginning.
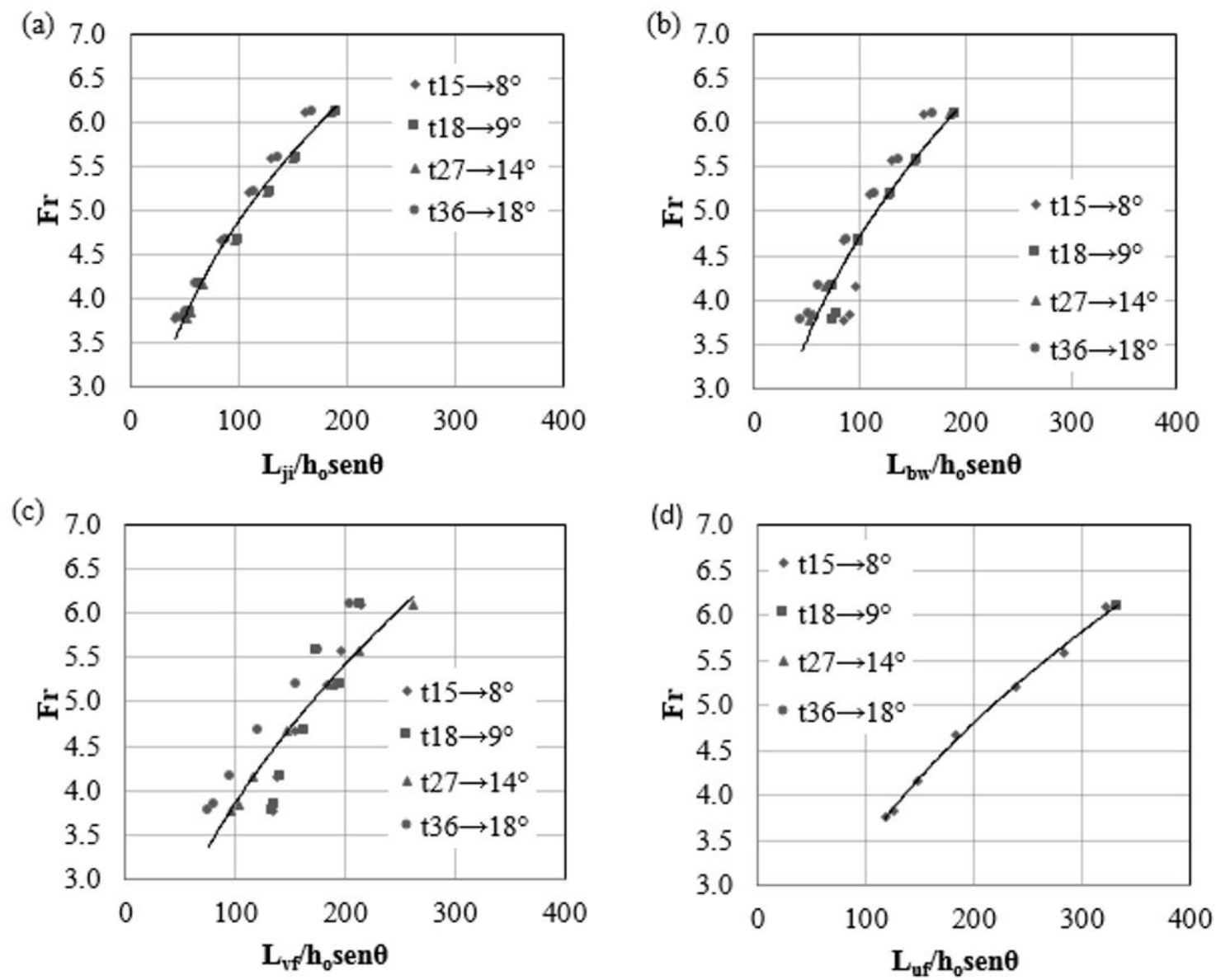

Figure 9. Adjusted equations for each characteristic position: (a) Jet impact; (b) blackwater reduction end; (c) gradually varied flow beginning; and (d) quasi-uniform flow beginning. 
Table 2. Coefficients obtained for Equation 1 for each characteristic position.

\begin{tabular}{lcccc}
\hline \multicolumn{1}{c}{ Characteristic position } & Lref & a & b & R2 \\
\hline Jet Impact & Lji & 0.89 & 0.367 & 0.97 \\
Blackwater reduction end & Lbw & 0.73 & 0.40 & 0.85 \\
Gradually varied flow beginning & Lvf & 0.40 & 0.49 & 0.74 \\
Quasi-uniform flow beginning & Luf & 0.40 & 0.47 & 0.99 \\
\hline
\end{tabular}

positions referred, when Re and We increases, all the positions occur further downstream.

However, Kobus (1984), Koschitzky et al. (1984) and Boes (2000) concluded that the Re number must be higher than $1 \times 10^{5}$ in order to avoid scale effects. Considering these authors conclusions, all the discharges tested in the present research are included in this limit (Table 1). According with Rutschmann (1988), for Webber numbers above 110, the scale effects can be neglected, in this case, the tested specific discharges higher than 0,275 satisfy the condition. Whereas the physical model utilized on the present research is on the scale of 1:10 and, accordingly to Pinto (1982), Volkart \& Rutchmann (1991) among others, physical models with scale from 1:10 to 1:15 are enough to avoid scale effects.

\section{CONCLUSIONS}

Tests conducted in the reduced scale physical model were performed with the purpose of allowing a better understanding of the behavior of a flow over stepped spillway with induced aeration by deflector and air chamber. Through visual analysis, it was observed three main regions: jet generation, blackwater reduction and fully aerated. The fully aerated region can be subdivided in another three regions: transition, gradually varied flow and quasi-uniform flow.

In order to characterize the influence of changing the deflector height on each region length and location, the following regions limits were observed for all the conducted tests: jet impact, blackwater reduction end, gradually varied flow beginning and quasi-uniform flow beginning. It was concluded that the specific discharge has little influence on jet length and greater influence on the aforementioned characteristics positions. However, the deflector height has a significant influence on all the characteristic positions. Increasing the deflector height, it was observed that the main regions developed further downstream in relation to lower deflectors. Moreover, the impact of the jet generated by the deflectors of $\mathrm{t} 27$ and $\mathrm{t} 36$ occurred downstream the step 12, which means that many steps were not in contact with the flow. This can be not desirable of the energy dissipation point of view, because the flow is not in proper condition to reach the dissipation structure downstream the chute. Thus, it can be concluded, for short chutes, like represented in this physical model, that is recommended to use the deflectors $\mathrm{t} 15$ and $\mathrm{t} 18(0.167 \leq \mathrm{t} / \mathrm{hd} \leq 0.200)$. However, more studies are necessaries about pressures and air concentration levels on the chute bottom to ensure the performance of these aerators. Although some evaluation of the quantity of air can be seen near of the chute bottom over all the spillway for these deflectors. For the same reasons it is not recommended to use the deflectors $t 27\left(\mathrm{t} / \mathrm{h}_{\mathrm{d}}=0.167\right)$ and $\mathrm{t} 36\left(\mathrm{t} / \mathrm{h}_{\mathrm{d}}=0.167\right)$. $(\mathrm{t} / \mathrm{hd}>0.200)$.
In addition, the characteristic position data, obtained on the tests were plotted with the Froude number as a function of the depth over the deflector and deflector angle. This equation of potential type was adjusted and approximately can be used to predict the location of each characteristic position for a determinate stepped spillway prototype.

\section{ACKNOWLEDGEMENTS}

The authors thank Furnas Centrais Elétricas S.A. for the financing of the research as well as CAPES and CNPQ. They also thank the team of the Laboratório de Obras Hidráulicas to his assistance to conduct the tests and data collection for the presented analysis.

\section{REFERENCES}

Amador, A., Sánchez-Juny, M., \& Dolz, J. (2009). Developing flow region and pressure fluctuations on steeply sloping stepped spillways. Journal of Hydraulic Engineering, 135(12), 1092-1100.

Boes, R. M. (2000). Scale effects in modeling two-phase stepped spillway flow. In H. E. Minor, W.H. Hager (Eds.), Hidraulics of stepped spillways (pp. 53-60). Rotterdam: Balkema.

Boes, R. M., \& Hager, W. H. (2003). Two-phase flow characteristics of stepped spillways. Journal of Hydraulic Engineering, 129(9), 661-670.

Chanson, H. (1994). Hydraulics of skimming flows over stepped channels and spillways. Journal of Hydraulic Research, 32(3), 445-460.

Gomes, J. F. (2006). Campo de pressões: condições de incipiência à cavitação em vertedouros em degraus com declividade 1V:0,75H (Tese de doutorado). Instituto de Pesquisas Hidráulicas, Universidade Federal do Rio Grande do Sul, Rio Grande do Sul.

Gonzalez, C. A., \& Chanson, H. (2007). Hydraulic design of stepped spillways and downstream energy dissipators for embankment dams. Dam Engineering, 17(4), 223-244.

Kobus, H. (1984). Hydraulic modelling. Berlim: IAHR.

Koschitzky, H., Westrich, B., \& Kobus, H. (1984). Effects of model configuration flow conditions and scale in modeling spillway aeration grooves. In Proceedings of the Symposium on Scale Effects in Modelling bydraulic structures (pp. 1-5). Netherlands: IAHR. 
Matos, J. S. G., Quintela, A., \& Ramos, C. M. (2001). Sobre a proteção contra erosão de cavitação em descarregadores de cheias em degraus. Lisboa: APRH.

Mojtaba, S., Habib, M. J., Mahmood, S. B., \& Aliereza, K. H. A. (2015). Experimental study of effect of installing deflector on replacement of inception point of air entrainment in stepped spillways. Journal of Scientific Research and Development, 3(4), 11-16.

Novakoski, C. K., Priebe, P. S., Canellas, A. V. B., Saraiva, L. S., Daí Prá, M., Sanagiotto, D. G., Osmar, F. M., Pinto, L. C. S., Marques, M. G., \& Matos, J. (2018). Extreme negative pressures and cavitation tendency on steeply sloping spillways. In Proceedings of the 3rd International Dam World Conference. Porto Alegre: UFRGS. Retrieved in 2019, April 18, from https://lume.ufrgs.br/bitstream/ handle $/ 10183 / 187234 / 001082448 . p d f$ ? sequence $=1$ \&isAllowed $=y$

Parsaire, A., Haghiabi, A. H., Saneie, M., \& Torabi, H. (2016). Prediction of energy dissipation on the stepped spillway using the multivariate adaptativa regression splines. ISH Journal of Hydraulic Engineering, 22(3), 281-292.

Peterka, A. J. (1953). The effect of entrained air on cavitation pitting. In Proceedings of the Minnesota International Hydraulic Convention. Minneapolis: ASCE.

Pfister, M., \& Hager, W. (2009). Deflector-gererated jets. Journal of Hydraulic Research, 47(4), 466-475.

Pfister, M., \& Schwindt, S. (2014). Air concentration distribution in deflector-jets. In Proceedings of the International Symposium on Hydraulic Structures (pp. 25-27). Brisbane: IAHR.

Pfister, M., Hager, W. H., \& Minor, H. (2006). Bottom aeration of stepped spillways. Journal of Hydraulic Engineering, 132, 850-853.

Pinto, N. (1982). Model prototype conformity in aerated spillway flow. In Proceedings of the International Conference on the Hydraulic Modeling of Civil Engineering Structures (pp. 273-284). Coventry, England: BHRA Fluid Engineering.

Rutschmann, P. (1988). Belüftungseinbauten in Schussrinnen (Chute aerators). In D. Vischer (Ed.), Mitteilung 97. Zurich: Laboratory of Hydraulics, Hydrology and Glaciology, ETH.

Sánchez-Juny, E., Bladé, E., \& Dolz, J. (2008). Pressures on a stepped spillway. Journal of Hydraulic Research, 45(4), 505-511.

Teng, P., Yang, J., \& Pfister, M. (2016). Studies of two-phase flow at a chute aerator with experiments and CFD modeling. Modellin and Simulation in Engineering, 2016, 1-11. http://dx.doi. org/10.1155/2016/4729128.

Terrier, S. (2016). Hydraulic performance of stepped spillway aerators and related downstream flow features (Doctoral thesis) Laboratory of Hydraulic Constructions, École Polytechnique Fédérale de Lausanne, Lausanne.
Volkart, P., \& Rutchmann, P. (1991). Aerators on spillways. In I. R. Wood (Ed.), Air entrainment in free-surface flows (pp. 85-130). Netherlands: IAHR.

Xu, W., Luo, S., Zheng, Q., \& Luo, J. (2015). Experimental stusy on pressure and aeration characteristics in stepped chute flows. Science China. Technological Sciences, 58(4), 720-726.

Yang, J., Teng, P., \& Xie, A. Q. (2018). Modeling of air demand of a spillway aerator with two-phase flow models. In Proceedings of the 2nd International Symposium on Hydraulic Modelling and Measuring Technology Congress (pp. 1-8). Nanjing: IAHR.

Zhang, G., \& Chanson, H. (2016). Hydraulics of the developing flow region of stepped spillways. I: physical Modeling and boundary layer development. Journal of Hydraulic Engineering, 142(7), 1-8.

Zhang, G., \& Chanson, H. (2017). Self aeration in the rpidlyand gradually-varying flow regions of steep smooth and stepped spillways. Environmental Fluid Mechanics, 17, 27-46.

Zhang, G., \& Chanson, H. (2018). Application of local optical flow methods to high-velocity free-surface flows: validation and application to stepped chutes. Experimental Thermal and Fluid Science, 90, 186-199.

Zhang, J., Chen, J., \& Wang, Y. (2012). Experimental study on time-averaged pressures in stepped spillway. Journal of Hydraulic Research, 50(2), 236-240.

Zindovic, B., Vojt, P., Kapor, R., \& Savic, L. (2016). Converging stepped spillway flow. Journal of Hydraulic Research, 54(6), 699-707.

\section{Authors contributions}

Carolina Kuhn Novakoski: Methodology elaboration, data analysis, graphics elaborations, bibliographic review, text elaboration.

Rute Ferla: Methodology elaboration, data analysis, text review.

Maurício Dai Prá: Methodology elaboration, data analysis, text review.

Alba Valéria Brandão Canellas: Model conception, data analysis, text review.

Marcelo Giulian Marques: Model conception, methodology elaboration, data analysis, text review.

Eder Daniel Teixeira: data analysis, text review. 